\title{
STUDI POTENSI TEMPAT PEMBUANGAN AKHIR (TPA) SAMPAH "PUTRI CEMPO” SURAKARTA SEBAGAI SUMBER PAKAN SAPI POTONG
}

\section{STUDY OF FINAL PLACE OF EXILE GARBAGE " PUTRI CEMPO" SURAKARTA AS FEED SOURCE OF BEEF CATTLE}

\author{
Sudiyono dan Eka Handayanta \\ Jurusan Peternakan Fakultas Pertanian Universitas Sebelas Maret Surakarta
}

\begin{abstract}
ABSTRAK
Penelitian ini bertujuan untuk mengetahui potensi dari tempat pembuangan sampah akhir ( TPA) Putri Cempo Surakarta sebagai sumber pakan sapi potong. Penelitian dilaksanakan selama enam bulan di beberapa lokasi antara lain 1) TPA sampah "Putri Cempo" Mojosongo Surakarta, untuk pengambilan sampel sampah 2) Laboratorium Biokimia Nutrisi Fakultas Peternakan UGM untuk analisis proksimat (kandungan nutrien) sampel sampah (organik), 3). Laboratorium Pengujian Veteriner Balai Besar Veteriner (BBVET), Wates Yogyakarta untuk analisis kandungan logam berat ( $\mathrm{Pb}$ dan $\mathrm{Hg}$ ) pada sampah organik. Hasil pengambilan sampel (sampling) sampah yang dibuang ke TPA "Putri Cempo" dan dipisahkan antara sampah organik dan sampah anorganik, terlihat bahwa jumlah sampah organik jauh lebih banyak daripada yang anorganik. Jumlah sampah organik dari masing-masing sumber sampah yang dibuang di TPA, diantaranya sampah domistik adalah 63,82\%, sampah pasar adalah 83,21\% dan sampah umum 67,53\%. Hasil analisis proksimat terlihat bahwa kandungan protein (PK) sampah organik berkisar antara 10,00 - 12,79\%. dan bahan kering (BK) 26,88-34,01 \%. Berdasarkan kandungan bahan keringnya, maka total BK sampah organik selama 5 (lima) tahun terakhir adalah berkisar antara 15,81 - 16,56 ribu ton/tahun, jika diasumsikan bakalan sapi potong yang digemukan dengan bobot badan $300 \mathrm{Kg} / \mathrm{ekor}$ dan kemampuan mengkonsumsi pakan (dalam BK) sebesar 3\% bobot badan (9 Kg/ekor/hari atau 3.285 Kg/ekor/tahun) maka sampah organik tersebut dapat mencukupi 4812 - 5041 ekor. Kandungan logam berat Timbal atau Plumbum (Pb) dari sampah organik yang dibuang ke TPA "Putri Cempo" Surakarta sebesar 12,34 ppm adalah cukup tinggi. Kesimpulan yang diperoleh dari hasil penelitian ini bahwa TPA Putri Cempo Surakarta, potensial sebagai sarana penggembalaan ternak sapi potong, mengingat jumlah sampah organik (Bahan Kering) yang dibuang secara kuantitatif cukup besar yakni 15,81 - 16,56 ribu ton /tahun dan secara kaulitatif masih mengandung nutrien yang cukup baik yang dapat dimanfaatkan oleh sapi potong, akan tetapi tercemar oleh Timbal atau Plumbum (Pb), tetapi tidak tercemar oleh Mercury atau Hydrogyrum (Hg).
\end{abstract}

\section{ABSTRACT}

This Research aim to to know the potency from place of exile final garbage Putri Cempo Surakarta as feed source of beef cattle. Research executed during six-month at some locations, there are: 1) TPA Garbage " Putri Cempo" Mojosongo Surakarta, for the intake of sampel garbage 2) Biochemical and Nutrition Laboratory,Faculty of Animal Husbandry UGM to analyse proximat of feed organic garbage 3). Laboratory of BBVET, Wates Yogyakarta for the analysis of content heavy metal ( $\mathrm{Pb}$ and $\mathrm{Hg}$ ) on organic garbage. Result of intake sample garbage thrown to TPA " Putri Cempo" and dissociated by organic garbage and inorganic garbage, showed that amount of organic garbage much more many than inorganic. Amount of organicmatter of garbage from each the source of garbage thrown in TPA, among others garbage domestic was $63,82 \%$, market garbage was $83,21 \%$ and public garbage $67,53 \%$. Result analyse the proksimat seen [by] that protein content ( organic PK) Garbage range from 10,00 - 12,79\%. and dry matter (DM) 26,88-34,01\%. Pursuant to its the dry matter content, hence totalizeing organic BK garbage during five the last year ware range from 15,81 - 16,56 thousand ton / year, if assumed by beef cattle potencially which fattening with the body wight $300 \mathrm{~kg} / \mathrm{head}$, go with the tide and ability consume feed ( in DM) equal to $3 \%$ body wight ( $9 \mathrm{Kg} / \mathrm{head} /$ day or $3.285 \mathrm{~kg} / \mathrm{head} /$ year) hence the organicmatter of garbage can answered the demand of 4812 - 5041 head of beef cattle. The garbage was conttent of heavy metal of lead $(\mathrm{Pb})$ from organic garbage, but the trace content of mercury $(\mathrm{Hg})$ 


\section{PENDAHULUAN}

Seiring dengan kemajuan peradaban masyarakat, kebutuhan dasar kehidupan yang pada awalnya hanya berupa pangan, sandang dan papan, perlu ditambah dengan kebutuhan dasar lainnya yakni yang berupa kesehatan dan pendidikan. Pada pemenuhan kebutuhan pangan, dengan semakin meningkatnya taraf hidup, kesejahteraan dan tingkat pendidikan masyarakat, maka pemenuhan kebutuhan pangan dituntut memenuhi kecukupan gizinya. Dengan kemampuan yang cukup dalam menyediakan bahan pangan, maka terjadilah perubahan gaya hidup yang tampak pada pola konsumsi makanan, baik secara kuantitatif maupun kualitatif. Pola konsumsi yang pada awalnya berkisar pada upaya pemenuhan kebutuhan pangan pokok saja, akan bergeser dan terus berkembang kearah pemenuhan kebutuhan pangan yang bergizi tinggi. Bahan pangan yang bergizi tinggi pada umumnya diperoleh dari produk hewan/ternak (hewani)

Hasil penelitian menunjukkan bahwa bahan pangan hewani memiliki kelebihan dibanding dengan bahan pangan nabati. Bahan pangan hewani mengandung protein dengan komposisi asam amino essensial yang lebih lengkap, mengandung lebih banyak vitamin dan mineral yang mudah diserap oleh tubuh seperti misalnya vitamin A, B12, dan D3, serta mineral Fe, Zn, Se, Ca dan $\mathrm{Cu}$, mempunyai nilai cerna protein yang lebih tinggi, dapat meningkatkan produktifitas kerja dan daya tahan tubuh terhadap penyakit. Kelebihan lainnya adalah dapat meningkatkan tingkat kecerdasan seseorang. Hal ini terkait dengan bahan-bahan essensial untuk pemebentukan otak adalah protein berkualitas, lemak dan kolesterol, dimana bahan-bahan tersebut berasal dari bahan pangan hewani. Disamping itu Asetilcholin yang merupakan bahan untuk mensintesa neurotransmiter banyak terdapat pada daging dan telur.

Mengingat peranan bahan pangan hewani , khususnya daging tersebut maka permintaan dan konsumsi daging semakin meningkat dari waktu ke waktu. Dalam rangka untuk memenuhi permintaan daging yang semakin meningkat tersebut, maka diperlukan peningkatan produktifitas ternak-ternak penghasil daging. Salah satu ternak yang potensial sebagai penghasil daging adalah sapi potong. Bahkan pemerintah melalui Ditjen. Peternakan Departemen Pertanian RI mencanangkan program swasembada daging tahun 2010. Keberhasilan program ini perlu dukungan dari pemerintah pusat, daerah, perguruan tinggi, swasta dan stake holder lainnya. Seperti diketahui bahwa tujuan program swasembada daging 2010 diantaranya adalah meningkatkan ketersediaan daging (khususnya daging sapi) untuk memenuhi permintaan konsumsi masyarakat, mengurangi ketergantungan impor daging dan atau sapi serta meningkatkan efisiensi dan efektifitas usaha budidaya ternak sapi.

Dalam pengembangan populasi sapi potong, pakan merupakan faktor utama yang menentukan produktifitas serta biaya produksinya. Seperti diketahui bahwa biaya pakan dapat mencapai 70 - 80 persen dari biaya produksi. Berbagai upaya telah dilakukan dalam mencari alternatife budidaya sapi potong dengan menggunakan pakan yang seefisien mungkin. Salah satunya adalah pemeliharaan/penggembalaan sapi potong di Tempat Pembuangan Akhir (TPA) sampah. Kenyataan di lapangan menunjukkan bahwa lebih dari 1000 ekor sapi potong digembalakan di TPA sampah "Putri Cempo" Mojosongo, Surakarta.

Kegiatan penggembalaan sapi di TPA sampah dapat memberikan keuntungan yakni dapat memanfaatkan barang yang sudah tidak berguna (sampah) menjadi produk yang lebih bermanfaat dan memiliki nilai ekonomis tinggi yakni daging sapi yang merupakan sumber protein hewani serta dapat meningkatkan pendapatan peternak melalui kepemilikan sapi potong. Tetapi disisi lain keamanan pangan (daging) dari sapi yang digembalakan di lokasi TPA sampah diragukan keamannya karena dicurigai terkontaminasi logam berat. Mengingat TPA sebagai tempat pembuangan berbagai macam sampah yang kemungkinan mengandung logam berat, sehingga apabila terkonsumsi oleh sapi akan terakumulasi di dalam tubuh (daging) sapi yang pada konsentrasi yang tinggi (melebihi ambang batas) akan membahayakan konsumen yang mengkonsumsi daging sapi tersebut. Namun demikian beberapa penelitian yang telah dilakukan memberikan hasil yang berbeda. Di Jawa Barat, sapi-sapi yang digembalakan di TPA sampah Ciangir Tasikmalaya, terbukti tidak tercemar logam berat (Anonimus, 2006 ), sedangkan di Semarang sapi-sapi yang digembalakan di TPA sampah Jatibarang tercemar logam berat khususnya Timbal $(\mathrm{Pb})$ (Anonimus, 2006 ${ }^{\mathrm{a}}$ ). Keadaan ini membuktikan bahwa adanya perbedaan kandungan logam berat yang terkandung di dalam daging sapi yang digembalakan di loksai TPA sampah yang berbeda. Hal ini diduga karena adanya pebedaan karakteristik sampah yang dibuang di lokasi TPA sampah. 
Berdasarkan hal tersebut diatas, maka perlu dilakukan penelitian (studi) tentang potensi TPA sampah sebagai tempat penggembalaan sapi potong dan kandungan logam berat dari sampah (organik) yang dibuang di " Putri Cempo" Mojosongo Surakarta.

\section{METODE PENELITIAN}

\section{Lokasi dan Waktu Penelitian}

Penelitian ini dilaksanakan di beberapa lokasi antara lain 1) TPA sampah "Putri Cempo" Mojosongo Surakarta, untuk pengambilan sampel sampah 2) Laboratorium Biokimia Nutrisi Fakultas Peternakan UGM untuk analisis proksimat (kandungan nutrien) sampel sampah (organik), 3). Laboratorium Pengujian Veteriner Balai Besar Veteriner (BBVET), Wates Yogyakarta untuk analisis kandungan logam berat ( $\mathrm{Pb}$ dan $\mathrm{Hg}$ ) pada sampah organik. Pelaksanaan penelitian memerlukan waktu 6 bulan, yang meliputi beberapa tahapan diantaranya : persiapan, identifikasi sampah, koleksi sampel sampah, analisis proksimat dan kandungan logam berat ( $\mathrm{Pb}$ dan $\mathrm{Hg}$ ) pada sampah organik, tabulasi dan analisis data serta penulisan laporan.

\section{Materi dan Alat Penelitian}

1. Seperangkat peralatan untuk pengabilan sampel sampah antara lain : pakaian lapangan (wear pack, masker, sepatu booth, sarung tangan), keranjang sampah, kantong-kantong plastik dan lembaran plastik.

2. Timbangan

Timbangan yang digunakan dalam penelitian ini adalah untuk menimbang sampel sampah.

3. Seperangkat alat dan kemikalia untuk analisis proksimat sampel sampah

(organik), dan analisis kandungan logam berat ( $\mathrm{Pb}$ dan $\mathrm{Hg}$ ) pada sampah organik.

\section{Jalannya Penelitian}

1. Persiapan penelitian

Persiapan penelitian dilakukan dengan cara survey ke lokasi untuk menentukan waktu pengambilan sampel sampah yang dibuang ke TPA sampah "Putri Cempo" Mojosongo.

2. Pengambilan sampel sampah

Pengambilan sampel sampah dibedakan menurut pengelolanya. Sampah domistik yakni sampah yang dikelola oleh Dinas Kebersihan Perkotaan (DKP), sampah pasar yakni sampah yang dikekola Dinas Pengelolaan Pasar (DPP) dan sampah umum yakni sampah yang dikelola oleh masyarakat umum secara mandiri. Dari setiap jenis sampah tersebut diambil sebesar 20 persen dari frekuensi pembuangan yang dilakukan yang menggunakan armada (colt dan atau truk). Untuk armada truk diambil $50 \mathrm{Kg}$ dan untuk colt diambil $25 \mathrm{Kg}$. Sampel sampah yang diperoleh dipisahkan antara sampah organik (edible) dengan sampah anorganik (non edible). Dari sampel sampah organik (edible) diambil 10 persen untuk dikeringkan dan dilakukan komposit sebelum dilakukan analisis proksimat dan kandungan $\mathrm{Pb}$ dan Hg-nya.

3. Analisis Proksimat dan kandungan $\mathrm{Pb}$ serta Hg sampah

Sampel sampah organik dianalisis proksimat untuk mengetahui kandungan nutriennya serta dianilisis kandungan logam berat khususnya $\mathrm{Pb}$ dan $\mathrm{Hg}$.

4. Analisis Hasil

Semua data yang diperoleh yakni, jumlah dan kualitas sampah, serta kandungan $\mathrm{Pb}$ dan $\mathrm{Hg}$ sampah organik dianalisis dan dilaporkan secara deskriptif.

\section{HASIL DAN PEMBAHASAN}

\section{Jumlah dan Jenis Sampah}

Tempat pembuangan akhir (TPA) sampah "Putri Cempo" berlokasi di Desa Jatirejo, Mojosongo, Kota Surakarta. Luas areal yang efektif untuk pembuangan sampah di TPA sampah "Putri cempo" Surakarta adalah $13 \mathrm{Ha}$, dari total areal TPA seluas $17 \mathrm{Ha}$. Sisanya luasannya digunakan sebagai areal untuk kantor, bengkel, dan jalan. Tempat pembuangan akhir (TPA) "Putri Cempo" Mojosongo didirikan/dibuka sejak tahun 1986. Berdasarkan pengelolanya, sampah yang dibuang ke TPA "Putri Cempo" dikelompokkan menjadi 3 (tiga) kelompok, yakni sampah domistik yang dikelola oleh Dinas Kebersiahan dan Pertamanan (DKP), sampah pasar yang dikelola oleh Dinas Pengelolaan Pasar dan sampah umum yang dikelola/dibuang oleh masyarakat umum secara mandiri langsung ke TPA.

Berdasarkan hasil pengambilan sampel (sampling) sampah yang dibuang ke TPA "Putri Cempo" dan dipisahkan antara sampah organik dan sampah anorganik, terlihat bahwa jumlah sampah organik jauh lebih banyak daripada yang anorganik. Jumlah sampah organik dari masingmasing sumber sampah yang dibuang di TPA, diantaranya sampah domistik (DKP) adalah 63,82\%), sampah pasar (DPP) adalah 83,21\% dan sampah umum (67,53\%).

Jenis/macam sampah (organik) yang dominan dari sampah domistik (DKP) adalah 
daun pisang, daun pohon-pohonan perdu dan kulit jeruk, sampah pasar (DPP) adalah daun bawang merah, daun bawang putih dan daun pisang dan untuk sampah umum adalah daun pisang, daun pohon-pohonan perdu dan kulit pisang. Sedangkan jenis sampah anorganik yang dibuang ke TPA dari ketiga sumber/pengelola pembuangan sampah yang dominan adalah plastik, kertas, kain, karet, dan gelas.

Berdasarkan hasil sampling di atas, maka potensi jumlah sampah organik yang dibuang ke TPA "Putri Cempo" selama 5 (lima) tahun terakhir seperti terlihat pada Tabel 1 . Dari tabel 1 terlihat bahwa jumlah sampah yang dibuang ke TPA "Putri Cempo" paling besar adalah sampah domistik (65,935 - 68,945 ribu ton/tahun) yang dikelola oleh DKP, diikuti oleh sampah pasar (10,131 - 10,956 ribu ton/tahun) yang dikelola DPP dan paling sedikit adalah sampah umum
$(1,821-2,497$ ribu ton/tahun) yang dikelola/dibuang langsung oleh masyarakat umum. Selama kurun 5 (lima) tahun terakhir, jumlah sampah organik yang dibuang ke TPA, untuk sampah domistik berkisar 42,080 - 44,001, sampah pasar berkisar 8,430 - 9,159, dan sampah umum 1,230 - 1,686 masing-masing dalam ribu ton. Sehingga total sampah organik yang dibuang ke TPA berkisar antara 51, 920 - 54, 371 ribu ton /tahun. Suatu jumlah yang sangat besar, yang apabila tidak dikelola sangat berpotensi bahan pencemar/polutan. Namun demikian dibalik potensi yang besar ini apabila dapat dimanfaatkan sebagai pakan ternak, khususnya sapi potong maka akan diperoleh keuntungan ganda (multiplier efect) yakni disatu sisi dapat mengurangi terjadinya pencemaran/polusi disisi lain dapat dipakai sebagai pakan sapi potong.

Tabel 1. Jumlah sampah yang dibuang di TPA "Putri Cempo" Mojosongo selama 5 tahun terakhir (ribu ton)

\begin{tabular}{lllllll}
\hline Sumber & Jenis & \multicolumn{5}{c}{ Tahun } \\
\cline { 3 - 7 } sampah & sampah & 2004 & 2005 & 2006 & 2007 & 2008 \\
\hline \multirow{2}{*}{ Domistik } & Total & 68,572 & 68,945 & 65,935 & 68,072 & 67,445 \\
& Organik & 43,763 & 44,001 & 42,080 & 43,444 & 43,043 \\
\multirow{2}{*}{ Pasar } & Total & 10,131 & 10,437 & 10,347 & 11,007 & 10,956 \\
& Organik & 8,430 & 8,684 & 8,610 & 9,159 & 9,116 \\
\multirow{2}{*}{ Umum } & Total & 2,322 & 2,497 & 1,821 & 2,402 & 2,091 \\
& Organik & 1,568 & 1,686 & 1,230 & 1,622 & 1,412 \\
Total & Organik & 53,761 & 54,371 & 51,920 & 54,225 & 53,571 \\
\hline
\end{tabular}

Sumber : Data sekunder DKP Kota Surakarta (2009)

Tabel 2. Kandungan Nutrien Sampah Organik TPA ”Putri Cempo” Mojosongo (\%)

\begin{tabular}{lcccccccc}
\hline \multirow{2}{*}{$\begin{array}{l}\text { Sumber } \\
\text { sampah }\end{array}$} & \multirow{2}{*}{ BK } & \multicolumn{7}{c}{ Persentase berdasarkan BK } \\
\cline { 3 - 7 } & & PK & LK & SK & Abu & Ca & P & \\
\hline Domistik & 34,01 & 10,00 & 7,05 & 19,24 & 23,09 & 2,827 & 0,153 & 40,62 \\
Pasar & 26,86 & 12,79 & 4,05 & 22,20 & 24,33 & 3,322 & 0,232 & 36,63 \\
Umum & 30,47 & 11,72 & 7,94 & 18,42 & 21,73 & 4,346 & 0,205 & 40,19 \\
\hline
\end{tabular}

Sumber : : Hasil analisis Lab. Biokimia Nutrisi, Fak. Peternakan UGM

Keterangan : BK : bahan kering

PK : protein kasar

LK : lemak kasar

SK : serat kasar

Ca : kalsium

$\mathrm{P} \quad$ : phospor

BETN: Bahan Ekstrak Tanpa Nitrogen

\section{Kandungan Nutrien Sampah Organik}

Hasil analisis laboratorium sampah organik yang dibuang di TPA "Putri Cempo" Mojosongo seperti terlihat pada Tabel 2. Dari hasil analisis laboratorium (proksimat) terlihat bahwa kandungan protein sampah organik berkisar antara 10,00 - 12,79\%. Kandungan ini lebih tinggi dari hijauan dari jenis rumput-rumputan, seperti rumput lapangan dengan PK 6,7\% dan SK
34,2\%, rumput Gajah PK 9,6\% dan SK 32,7\%, maupun hijauan dari limbah pertanian seperti jerami padi dengan PK 4,5\%, SK 35,5\%, pucuk tebu PK 4,9\% dan SK 33,5\%, jerami jagung PK 9,3\% dan SK 25,6\% (Siregar, 1994) .Dilihat kandungan protein kasarnya, sampah organik yang berasal dari sampah pasar hampir sama bahkan sedikit lebih tinggi daripada konsentrat komersial BC 133 untuk sapi potong yakni 
sebesar 12,236 \% (hasil analisis Lab. Ilmu Nutrisi dan Makanan Ternak Fak. Peternakan UNSOED Purwokerto, 2006) dan rumput Raja yakni sebesar 12,56\% (hasil analisis Lab. Biokimia Nutrisi Fak Peternakan UGM Yogyakarta, 2006). Berdasarkan kandungan bahan kering (BK)-nya, maka total BK sampah organik selama 5 (lima) tahun terakhir adalah berkisar antara 15,81 16,56 ribu ton/tahun. Bila diasumsikan bakalan sapi potong yang digemukan dengan bobot badan 300 Kg/ekor dan kemampuan mengkonsumsi pakan (dalam BK) sebesar $3 \%$ bobot badan (9 Kg/ekor/hari atau 3.285 Kg/ekor/tahun) maka sampah organik tersebut dapat mencukupi 4812 5041 ekor. Suatu potensi yang cukup besar yang dapat mendukung upaya peningkatan populasi dan produktifitas sapi potong dalam rangka mendukung program pemerintah terkait program peningkatan konsumsi protein hewani asal ternak. Bahkan dilihat dari sisi ekonominya, usaha peternakan di tempat sampah adalah sangat ekonomis, karena biaya pakan relatif tidak ada , kecuali bila peternak memberikan pakan tambahan. Padahal seperti diketahui bahwa biaya pakan merupakan biaya produksi terbesar dalam usaha peternakan termasuk pemeliharaan sapi potong.

\section{Kandungan Logam Berat pada Sampah Organik}

Kandungan logam berat khususnya Plumbum (Pb) dan Mercury atau Hydrogyrum (Hg) hasil analisis seperti terlihat pada Tabel 3 .

\begin{tabular}{llll} 
Tabel 3. Kandungan Pb dan Hg & Sampah \\
Organik TPA "Putri & Cempo" \\
Mojosongo (ppm) & & \\
\hline
\end{tabular}

\begin{tabular}{ccc}
\hline \multirow{2}{*}{ Jenis Sampah } & \multicolumn{2}{c}{ Kandungan (ppm) } \\
\cline { 2 - 3 } & $\mathrm{Pb}$ & $\mathrm{Hg}$ \\
\hline Sampah organik & 12,34 & $\left.<0,05^{*}\right)$ \\
\hline
\end{tabular}

Keterangan *) tidak terdeteksi dengan metode AAS Sumber : Hasil Analisis Lab. Pengujian Veteriner, Balai Besar Veteriner, Wates, Yogyakarta (2009)

Kandungan logam berat Timbal atau Plumbum $(\mathrm{Pb})$ dari sampah organik yang dibuang ke TPA "Putri Cempo" Surakarta sebesar 12,34 ppm adalah cukup tinggi. Hal ini dapat dipahami jika dikaitkan dengan jenis sampah anorganik yang dibuang ke TPA "Putri Cempo" yang kemungkinan besar sebagai faktor pencemarnya. Dari hasil penelitian ini diketahui bahwa jenis sampah anorganik yang dominan adalah plastik, kertas, kain, karet dan gelas. Sesuai dengan Anonimus (2009), bahwa di Indonesia komponen sampah anorganik yang dominan adalah kertas, plastik, logam, karet, tekstil, dan kaca/gelas.
Dari tiga jenis yang paling dominan tersebut (plastik, kertas dan kain) sangat potensial sebagai pencemar logam $\mathrm{Pb}$. Seperti diketahui bahwa $\mathrm{Pb}$ merupakan salah satu komponen bahan pembuatan plastik, tinta pada kertas koran dan zat pewarna pada kain.

Dari hasil penelitian ini menunjukkan bahwa dari sampah organik tidak terdetekasi adanya kandungan logam berat Mercury atau Hydrogyrum (Hg). Artinya dengan penetapan menggunakan metode AAS, kandungan $\mathrm{Hg}$ kurang dari 0,05 ppm (karena batas deteksi AAS adalah 0,05 ppm). Hal ini dapat dipahami karena faktor utama pencemar $\mathrm{Hg}$ adalah limbah penambangan (tailing). Dan di wilayah kota Surakarta jauh dari aktifitas penambangan, sehingga faktor pencemar $\mathrm{Hg}$ adalah sangat kecil. Seperti diketahui bahwa Hg adalah unsur kimia yang termasuk logam berat dan telah lama digunakan untuk menambang emas. Untuk kepentingan penambangan $\mathrm{Hg}$ dianggap mudah digunakan, relatif efisien dan harganya murah.

Hal yang sangat dikawatirkan adalah sampah-sampah organik yang telah tercemar logam berat ( $\mathrm{Pb}$ maupun $\mathrm{Hg}$ ) tersebut dikonsumsi (sebagai pakan) oleh sapi-sapi potong yang digembalakan di TPA. Logam berat ( $\mathrm{Pb}$ dan $\mathrm{Hg}$ ) merupakan unsur kimia yang di dalam tubuh tidak bisa dicerna dan bersifat bioakumulatif (Sinaga, 2004). Residu yang terdapat di dalam jaringan tubuh ternak (daging) akan berbahaya bila dikonsumsi oleh manusia yang mengkonsumsi. Karena dampak yang ditimbulkan dapat dirasakan bertahun-tahun kemudian. Gangguan yang tibul akibat keracunan Plumbum $(\mathrm{Pb})$ adalah pada fungsi jaringan dan metabolisme, mulai dari sintesis Hemoglobin $(\mathrm{Hb})$, ginjal, system syaraf, system reproduksi dan fungsi paru-paru, sedangkan akibat keracunan Mercury (Hg) dapat menimbulkan gangguan berupa rusaknya keseimbangan, tidak bisa berkonsentrasi, tuli dan gangguan seperti kasus Minamata yakni diataranya panas pada anggota badan, mulut, bibir dan lidah, serta sulit berbicara dan menelan (Sinaga, 2004), merusak sistem saraf pusat, organ-organ reproduksi, dan sistem kekebalan tubuh.

\section{KESIMPULAN DAN SARAN}

\section{Kesimpulan}

Kesimpulan yang diperoleh dari hasil penelitian ini adalah bahwa Tempat Pembuangan (TPA) sampah "Putri Cempo" Mojosongo Surakarta memiliki potensi yang cukup besar sebagai sarana penggembalaan ternak sapi potong, mengingat jumlah sampah organik 
(Bahan Kering) yang dibuang ke TPA yang secara kuantitatif cukup besar yakni 15,81 16,56 ribu ton /tahun dan secara kaulitatif masih mengandung nutrien yang cukup baik yang dapat dimanfaatkan oleh sapi potong. Sampah organik di TPA "Putri cempo" tercemar oleh Timbal atau Plumbum (Pb), tetapi tidak tercemar oleh Mercury atau Hydrogyrum (Hg).

\section{Saran}

Oleh karena potensi TPA sebagai tempat penggembalaan sapi cukup besar, akan tetapi karena sampah organiknya (sebagai pakan sapi) tercemar oleh $\mathrm{Pb}$ maka diperlukan penelitian lebih lanjut untuk mencari metode/cara untuk menurunkan/menghilangkan kandungan $\mathrm{Pb}$ dalam sampah organik agar ternak sapi yang mengkonsumsi tidak tercemar dan produk sapinya (daging) aman dikonsumsi manusia.

\section{DAFTAR PUSTAKA}

Anggorodi, R. 1990. Ilmu Makanan Ternak Umum. PT Gramedia. Jakarta.

Anonimus. 2004. Bahaya Cemaran Logam Berat. Pikiran Rakyat, 29 Juli 2004.

Anonimus. 2006 ${ }^{\mathrm{a}}$. Sapi Tercemar Logam Berat. Kompas, 18 September 2006.

Anonimus. 2006 b. Dites, Darah dan Daging Sapi di Sekitar TPA Ciangir. Kompas, 2 Nopember 2006.

Anonimus, 2009. Modul Pelatihan 3 R. Direktorat Pengembangan Penyehatan

Lingkungan Pemukiman. Direktorat Jendral Cipta Karya. Departemen Pekerjaan Umum. Jakarta.

Bahar, Y.H. 1986. Teknologi Penanganan dan Pemanfaatan Sampah. PT.Waca Utama Pramesti. Jakarta

Badan POM RI. 2003. Peraturan di Bidang Pangan. Dit.Surveilan dan Penyuluhan Keamanan Pangan. Deputi Bidang Pengawasan Keamanan Pangan dan Bahan Berbahaya. Jakarta
Cullison, A.E. 1979. Feed and Feeding. 2nd eds. Reston Publ. Co., Ic. Reston, Virginia.

Dyer, I.A. and R.P. Kromann. 1977. Cattle Feeding. In : The Feedlot. Dyer, I.A and C.C.O. Marry ed. Lea ad Febiger. Philadelphia

Irawati, D.A. 1999. Kinerja Sapi Peranakan Ongole yang Digembalakan di Lokasi Tempat Pembuangan Akhir Mojosongo Surakarta. Tesia S-2. Program Pasca Sarjana UGM. Yogyakarta.

NRC, 1976. Nutrient Requirement of Beef Cattle. 5 th eds. National Academy of Sciences. Washington.

Sinaga, S.M. 2004. Perspektif Pengawasan Makanan dalam Kerangka Keamanan Makanan dan untuk Meningkatkan Kesehatan. Pidato Pengukuhan Jabatan Guru Besar Tetap F.MIPA. USU. Medan

Tillman, A.D., H.Hartadi dan R. Reksohadiprodjo, 1991. Ilmu Makanan Ternak Dasar. Gadjah Mada Univ. Press. Yogyakarta.

Winarno, F.G. 2004. Keamanan Pangan. M-Brio Press. Bogor. 